\title{
Measuring relative efficiency of commercial banks in Bahrain using data envelopment analysis
}

\author{
Minwir Al-Shammari ${ }^{1}$, Seref Turen ${ }^{2}$, Mohamed S. Abou El-Seoud ${ }^{2}$ \\ ${ }^{1}$ Department of Management and Marketing, College of Business Administration, University of Bahrain, Kingdom of Bahrain \\ ${ }^{2}$ Department of Economics and Finance, College of Business Administration, University of Bahrain, Kingdom of Bahrain
}

Email address:

minwir@gmail.com (M. Al-Shammari), sturen@uob.edu.bh (S. Turen), msayed@uob.edu.bh (M. S. A. El-Seoud)

\section{To cite this article:}

Minwir Al-Shammari, Seref Turen, Mohamed S. Abou El-Seoud. Measuring Relative Efficiency of Commercial Banks in Bahrain Using Data Envelopment Analysis. International Journal of Economics, Finance and Management Sciences. Vol. 2, No. 6, 2014 , pp. $297-305$. doi: $10.11648 /$ j.ijefm.20140206.11

\begin{abstract}
The study aims at measuring relative efficiency of seven banks listed on Bahrain Bourse under the commercial banks sub-sector over the period 2008-2012 by employing Data Envelopment Analysis (DEA) as a special linear programming model that assesses relative efficiency of decision-making units (DMUs) using multiple incommensurable input and multiple incommensurable output measures. By adopting the production approach of DEA with restricted choice of variables, the study has isolated the relatively efficient banks that achieved total efficiency score from those that could not achieve it. The study has also identified input and output slacks of inefficient banks and suggested the efficient input and output targets for improvement.
\end{abstract}

Keywords: Efficiency, Commercial Banks, DEA, Slacks, Linear Programming, Bahrain

\section{Introduction}

Commercial banks are one of the most important financial institutions of an economy. Many studies indicate that the efficiency of the financial intermediation of commercial banks affects economic growth and that the insolvencies of these banks can result in systemic crisis or initiate negative consequences for the economy. Therefore, the performance of commercial banks has been always an issue of great interest for various stakeholders such as regulators, shareholders, depositors and loan customers.

The banking sector has played an important role in the emergence of Bahrain as leading financial hub in the GCC Countries and in the region as well. According to the Fact Sheet of Central Bank of Bahrain, banking sector assets, as of July 2014, are over US\$193 billion with a 23 retail banks, 69 wholesale banks, 2 specialized banks as well as 36 representative offices of overseas banks. The Islamic banking segment offers Sharia compliant products with 6 retail banks and 18 wholesale banks, and has total assets of US\$24.6 billion. Bahraini banking sector over time has shown a tremendous growth. It is an open market. Government implements stable and prudent macro-economic and fiscal policies. Central Bank of Bahrain is keen to establish a credible regulatory framework in line with international standards. Local labor market offers very skillful and well qualified workforce. Bahrain has still an affordable cost of living compared to many of its neighbors. All these factors may have combined to secure Bahrain as a regional banking hub. Despite worldwide challenges, Bahrain has a stable banking system with observed growth opportunity in the sector.

This paper attempts not only to determine the commercial banks listed on Bahrain Bourse that have total relative efficiency based on the data available over the period of 2008 to 2012 but also to identify the banks which are unable to achieve that efficiency by exploring primary reasons lying behind. It also illustrates the efficient peers and weights of the banks and suggests the efficient input and output targets of inefficient ones by determining the inputs and outputs slacks. For this purpose, this study employs Data Envelopment Analysis (DEA) as a widely used a linear programming model to assess relative efficiency of decisionmaking units (DMUs), viz. banks, that use multiple incommensurable inputs and multiple incommensurable outputs.Study provides review of the literature; describes the data and presents the method; discusses empirical findings; and finally closes with concluding remarks. 


\section{Literature Review}

A large part of existing literature examines the efficiency of conventional banks using DEA. Examples of previous studies that used DEA to assess relative efficiency of banks include Marie et al (2013), Johnes et al. (2012), Qureshi et al. (2012), Bilal et al. (2011), Rahman (2011), Srairi (2011), AlKhathlan and Malik (2010), Shahid et al (2010), Srairi (2010), Kamaruddin et al. (2008), and Mostafa (2007).

Marie et al (2013) examined 18 banks in Dubai applying a parallel DEA to measure the operational profitability and quality in 2008 based on data collected from financial statements and randomly selected bank customers. They found no statistical difference between Islamic and commercial banks in the operational profitability, however, Islamic banks dominated the commercial ones in the operational quality. They also pointed out that operational quality in Islamic banks depended on the assurance, responsiveness and reliability factors.

Johnes et al. (2012) compared, using DEA approach, the performance of 210 conventional and 45 Islamic banks from 19 countries for the period 2004-2009. They found out that there was no significant difference in mean efficiency between the two types of banks when efficiency is measured relative to a common frontier. A meta-frontier analysis, however, revealed some fundamental differences between the two bank groups. They also emphasized that the Islamic banks was less efficient than the conventional one. Managers of Islamic banks made up for this as mean efficiency in Islamic banks was higher than in conventional banks when efficiency was measured relative to their own bank type frontier.

Qureshi et al. (2012) analyzed comparative efficiency of banking system in Pakistan by considering the Islamic banks, conventional banks with Islamic banking division and conventional banks across 2003-2008. They used both ratio analysis and DEA approach. The research results indicated that Islamic banks were more cost efficient and less revenue efficient. Considering their high growth rate, it was recommended that Islamic banks should be encouraged to reach the efficient frontier by reducing their wastes. It was also determined that hybrid banking is not feasible form of banking in Pakistan.

Bilal et al. (2011) investigated the efficiency of 5 private Islamic banks and 5 private conventional banks of Pakistan for 2006-2008. Non-parametric DEA method was used. Intermediation approach was applied for the specification of inputs and outputs. The findings suggested that scale inefficiency was dominated by the pure technical inefficiency effects in determining Islamic bank's technical inefficiency. It was concluded that Islamic banks were more efficient in operating at an optimum size though they were managerially not that much efficient. The opposite was valid for commercial banks.

Rahman (2011) examined the efficiency of Islamic and conventional banks in Bangladesh using different parametric and non-parametric approaches over the study period of
2003-2008. His results showed that conventional and Islamic banks improved and converged to the highest level of efficiency. Findings also showed that conventional banks were only slightly more efficient than Islamic banks.

Srairi (2011) examined, in the GCC region, the effects of financial liberalization on banking productivity growth for the period of 1999 and 2007. He, based on non-parametric DEA, measured productivity change computing a Malmquist total factor productivity index for Islamic and conventional banks. The results showed that during the deregulation period, banks in GCC region experienced a gain in productivity change attributed mainly to technical change rather than to an increase in efficiency. He also noted that conventional banks tended to outperform Islamic ones in most productivity measures.

AlKhathlan and Malik (2010) implemented DEA to ten commercial banks operating in Saudi Arabia to analyze both the technical and scale efficiencies of these banks during 2003-2008. They claimed that their findings showed that there was efficient management of financial resources by Saudi banks.

Shahid et al (2010) investigated the efficiency of banking sector in Pakistan based on DEA using data gathered both from Islamic and conventional banks over the period of 2005 and 2009. The findings indicated that the technical efficiency of conventional banks was better than the Islamic ones but about the cost and allocative efficiency, both groups show a healthy competition.

Srairi (2010) investigated 11 local commercial banks of Saudi Arabia for the period of 1999 and 2007. He adopted DEA so as to compute five different measures of efficiency including cost, allocative, technical, pure and scale efficiencies. He pointed out that the cost efficiency was below the world mean and during the period of liberalization between the years of 2003-2007, most efficiency scores slightly increased. The results also showed that the dominant source of cost efficiency was due to allocative inefficiency rather than technical one.

Kamaruddin et al. (2008) investigated both cost and profit efficiency of Islamic banks and Islamic window operations of domestic and foreign commercial banks over 1998-2004 in Malaysia. DEA was applied to several efficiency measures such as allocative, pure technical and scale efficiency. The findings revealed that Islamic banking operators were relatively more efficient at controlling cost than at generating profits.

Mostafa (2007) attempted to measure the relative efficiency of the top 100 Arab banks using cross sectional data via DEA for the year 2005. His findings indicated that the performances of several banks were sub-optimal.

\section{Model and Data}

DEA is commonly used to evaluate the efficiency of a group of production units (originally known as Decision Making Units DMUs) such as banks. In DEA, each DMU is compared with only the "best" DMUs. DEA computes a 
scalar measure of efficiency (called efficiency score) and determines efficient levels of inputs and outputs for the DMU under evaluation. In general there are two approaches that a DMU in a DEA model can be considered. The first is called the Intermediary Approach. According to this approach a bank is a financial vehicle that borrows funds from depositors and lends them for profit. In this case the banks' outputs are loans and the inputs are different costs of these funds such as interest expenses, labor, capital and operating costs. On the other hand, there is the Production Approach where a bank is an organization that uses capital and labor to produce loans and deposit account services. The banks' inputs are labor, capital and operating costs in order to produce accounts and transactions as outputs (Berger and Humphrey, 1997).

The current study adopts the production approach with restricted choice of variables in order to measure the efficiency of any DMU is obtained as the maximum of a ratio of weighted outputs to weighted inputs subject to the condition that the similar ratios for every DMU should be less than or equal to unity. In more precise form,

$$
\operatorname{Max} h_{0}=\sum_{\mathrm{r}=1}^{\mathrm{S}} \mathrm{u}_{\mathrm{r}} \mathrm{y}_{\mathrm{r} 0} \div \sum_{\mathrm{i}=1}^{\mathrm{m}} \mathrm{v}_{\mathrm{i}} \mathrm{x}_{\mathrm{i} 0}
$$

Subject to:

$$
\begin{aligned}
& \left\{\sum_{\mathrm{r}=1}^{\mathrm{S}} \mathrm{u}_{\mathrm{r}} \mathrm{y}_{\mathrm{ri}} \div \sum_{\mathrm{i}=1}^{\mathrm{m}} \mathrm{v}_{\mathrm{i}} \mathrm{x}_{\mathrm{ij}}\right\} \leq 1 ; \mathrm{j}=1,2, \ldots, \mathrm{n} . \\
& \mathrm{u}_{r}, v_{i} \geq 0 ; \quad r=1,2, \ldots S ; \quad i=1,2, \ldots, m
\end{aligned}
$$

The $\mathrm{y}_{\mathrm{rj}}, \mathrm{x}_{\mathrm{ij}}$ (all positive) are the known outputs and inputs of the $\mathrm{j}^{\text {th }}$ DUM and the ur, vi $\geq 0$ are the variable weights to be determined by the solution of this problem using the data on all of the DUM's which are being used as a reference set. The efficiency of one member of this reference set of $\mathrm{j}=1,2, . ., \mathrm{n}$ is to be rated relative to other DMUs. The indicated maximization objective function then accords this DMU the most favorable weighting that the constraints allow.

For the DMU's which concern us, the $\mathrm{x}_{\mathrm{ij}}$ and $\mathrm{y}_{\mathrm{rj}}$ values, which are constants, will usually be observations from past decisions on inputs and outputs that resulted there from. We can, however, replace some or all of these observations by theoretically determined values if we wish (and are able) to conduct our efficiency evaluations in that manner.

\subsection{Study Variables}

Banking sector employs multiple inputs to produce multiple outputs. To capture important components of banks' resources and outputs within the available data, three input variables and two output variables were sought to measure the technical relative efficiency, as shown in table (1)

Table 1. Input and Output Variables

\begin{tabular}{ll}
\hline Inputs & Output \\
\hline Total deposits & Net loans \\
Overhead expenses & Interest income \\
Total Owners' Equity & \\
\hline
\end{tabular}

The two outputs taken into consideration are net loans and interest income (which includes interest of bonds, certificates of deposit and other interest). On the other hand the inputs used are: total deposits, overhead expenses and equity. To ensure meaningful efficiency scores, the number of DMUs must be large enough to the total number of inputs and output as suggested by Boussofiane et al. (1991).

\subsection{Sources of Data}

The data for this study were collected from BANKSCOPE and commercial banks' annual reports. Table 2 shows the input and output variables of seven Bahraini retail commercial banks over the period (2008-2012), while Table 3 presents the descriptive statistics of the selected inputs and outputs for the same study period. All the data employed are expressed in Million Bahraini Dinars. Table 4 illustrates that there is strong correlation among study variables(input and

\begin{tabular}{|c|c|c|c|c|c|c|}
\hline \multirow{2}{*}{\multicolumn{2}{|c|}{ Variables Banks }} & \multicolumn{3}{|l|}{ Inputs } & \multicolumn{2}{|l|}{ Output } \\
\hline & & Total Deposit & Overhead Expenses & Equity & Net Loans & Interest Income \\
\hline \multirow{7}{*}{2008} & B1 & 13,075 & 53.9 & 726.6 & $4,895.10$ & 108.8 \\
\hline & B2 & $2,923.70$ & 35.1 & 209.3 & $1,352.30$ & 56.6 \\
\hline & B3 & $3,324.30$ & 24.1 & 217.4 & $1,095.70$ & 49.4 \\
\hline & B4 & 867.5 & 14.2 & 128.6 & 486.90 & 15.5 \\
\hline & B5 & 542.3 & 3.4 & 63.3 & 113.10 & 13.8 \\
\hline & B6 & $4,968.10$ & 57.6 & 902.8 & $5,139.30$ & 467.5 \\
\hline & B7 & 600.60 & 12.4 & 137.9 & 140.10 & 43.5 \\
\hline \multirow{7}{*}{2009} & B1 & 6,834 & 46.3 & 671.5 & $3,508.70$ & 77.9 \\
\hline & B2 & $3,273.40$ & 43 & 231 & $1,268.60$ & 57 \\
\hline & B3 & $3,346.20$ & 25.8 & 241.4 & $1,151.40$ & 52.7 \\
\hline & B4 & 747.7 & 15.3 & 112.6 & 388.00 & 15.3 \\
\hline & B5 & 530.4 & 3.5 & 73.7 & 118.40 & 13.2 \\
\hline & B6 & 4,992 & 53.6 & 973.2 & $5,014.10$ & 352.2 \\
\hline & B7 & 579.1 & 10.3 & 126.6 & 192.10 & 22 \\
\hline
\end{tabular}
output).

Table 2. Input and Output Data for 2008-2012 (Figures in million BDs) 


\begin{tabular}{|c|c|c|c|c|c|c|}
\hline \multirow{2}{*}{\multicolumn{2}{|c|}{ Variables Banks }} & \multicolumn{3}{|l|}{ Inputs } & \multicolumn{2}{|l|}{ Output } \\
\hline & & Total Deposit & Overhead Expenses & Equity & Net Loans & Interest Income \\
\hline \multirow{7}{*}{2010} & B1 & 6,086 & 37.1 & 723.8 & 2,834 & 58.9 \\
\hline & B2 & $3,384.40$ & 45.6 & 240.5 & $1,276.30$ & 56.6 \\
\hline & B3 & $3,768.80$ & 25.8 & 263 & 950.8 & 52.4 \\
\hline & B4 & 728 & 17.3 & 86.4 & 310 & 14.5 \\
\hline & B5 & 502.7 & 5.1 & 88.2 & 151.7 & 14.4 \\
\hline & B6 & $5,593.10$ & 53.7 & $1,037.60$ & $5,458.10$ & 336.8 \\
\hline & B7 & 503.60 & 16.3 & 118.2 & 203.2 & 17.9 \\
\hline \multirow{7}{*}{2011} & B1 & 7,121 & 45.2 & 740.7 & $2,547.80$ & 57 \\
\hline & B2 & $4,295.90$ & 47.9 & 238 & $1,406.70$ & 61.4 \\
\hline & B3 & $4,008.60$ & 26.7 & 274.7 & 972.1 & 60 \\
\hline & B4 & 936.1 & 18.9 & 82.9 & 349.6 & 13.6 \\
\hline & B5 & 513.2 & 5.1 & 96.6 & 141.2 & 20.9 \\
\hline & B6 & $6,539.10$ & 55 & $1,097.50$ & 5,842 & 367.2 \\
\hline & B7 & 553.70 & 17.2 & 118.9 & 201.6 & 21.6 \\
\hline \multirow{7}{*}{2012} & B1 & 8,212 & 51.4 & 803.8 & $2,683.10$ & 60.7 \\
\hline & B2 & 4,712 & 50.5 & 289.7 & $1,498.70$ & 67.9 \\
\hline & B3 & $4,399.70$ & 27.3 & 318.9 & 888.2 & 65.4 \\
\hline & B4 & $1,184.60$ & 18.7 & 85.4 & 499.1 & 15.5 \\
\hline & B5 & 518 & 6.2 & 104.5 & 112.7 & 20 \\
\hline & B6 & 6,880 & 56.2 & $1,206.40$ & $6,027.30$ & 404 \\
\hline & B7 & 576.8 & 15.3 & 119.5 & 245.7 & 16.6 \\
\hline
\end{tabular}

Source: Compiled from BANSCOPE and Commercial Banks' Annual Reports

Table 3. Descriptive Statistics

\begin{tabular}{lllllll}
\hline Years & & Total Deposit & Overheads Expenses & Equity & Net Loans & Interest Income \\
\hline \multirow{4}{*}{2008} & Maximum & 13,075 & 57.6 & 902.8 & $5,139.30$ & 467.5 \\
& Minimum & 542.30 & 3.4 & 63.30 & 113.1 & 13.80 \\
& Mean & 3,757 & 28.671 & 341 & 1888.929 & 108 \\
& Standard Deviation & 4102.61 & 19.451 & 307.155 & 2024.73 & 149.717 \\
& Maximum & 6,834 & 53.6 & 973 & 5014.1 & 352 \\
2009 & Minimum & 530 & 3.5 & 74 & 118.4 & 13 \\
& Mean & 2,900 & 28.257 & 347 & 1663.043 & 84 \\
& Standard Deviation & 2262.278 & 18.104 & 316.283 & $1,741.45$ & 111.621 \\
& Maximum & 6,086 & 53.7 & $1,037.60$ & 5458.1 & 336.80 \\
2010 & Minimum & 502.70 & 5.1 & 86.40 & 151.7 & 14.40 \\
& Mean & 2,938 & 28.7 & 365 & 1597.729 & 79 \\
& Standard Deviation & $2,222.97$ & 16.17 & 342.715 & 1798.67 & 106.998 \\
& Maximum & 7,121 & 55 & $1,097.50$ & 5842 & 367.20 \\
& Minimum & 513.20 & 5.1 & 82.90 & 141.2 & 13.60 \\
& Mean & 3,424 & 30.857 & 378 & 1637.286 & 86 \\
& Standard Deviation & 2618.74 & 17.276 & 375.974 & 1888.38 & 116.38 \\
& Maximum & 8,212 & 56.2 & 1206.4 & $6,027.30$ & 404 \\
& Minimum & 518 & 6.2 & 85 & 112.7 & 16 \\
& Mean & 3,783 & 32.228 & 418 & 1707.829 & 93 \\
& Standard Deviation & 2882.024 & 18.698 & 395.457 & 1944.508 & 128.912 \\
\hline
\end{tabular}

Source: Computed using Table (1) data

Table 4. Nonparametric Correlations

\begin{tabular}{|c|c|c|c|c|c|c|}
\hline & & Total Deposit & Overheads Expenses & Equity & Net Loans & Interest Income \\
\hline \multirow{3}{*}{ Total Deposit } & Correlation Coefficient & 1 & & & & \\
\hline & Sig. (1-tailed) & - & & & & \\
\hline & $\mathrm{N}$ & 7 & & & & \\
\hline \multirow{3}{*}{$\begin{array}{l}\text { Overheads } \\
\text { Expenses }\end{array}$} & Correlation Coefficient & $.905^{* *}$ & 1 & & & \\
\hline & Sig. (1-tailed) & 0.002 & - & & & \\
\hline & $\mathrm{N}$ & 7 & 7 & & & \\
\hline \multirow{3}{*}{ Equity } & Correlation Coefficient & $.619^{*}$ & $.714^{*}$ & 1 & & \\
\hline & Sig. (1-tailed) & 0.025 & 0.012 & - & & \\
\hline & $\mathrm{N}$ & 7 & 7 & 7 & & \\
\hline \multirow{2}{*}{ Net Loans } & Correlation Coefficient & $.905^{* *}$ & $1.000^{* *}$ & $.714^{*}$ & 1 & \\
\hline & Sig. (1-tailed) & 0.002 & & 0.012 & - & \\
\hline
\end{tabular}




\begin{tabular}{lllllll}
\hline & & Total Deposit & Overheads Expenses & Equity & Net Loans & Interest Income \\
\hline & $\mathrm{N}$ & 7 & 7 & 7 & 7 & \\
& Correlation Coefficient & $.829^{*}$ & $.724^{*}$ & $.819^{*}$ & $.924^{*}$ & 1 \\
Interest Income & Sig. (1-tailed) & 0.008 & 0.049 & 0.025 & 0.049 & - \\
& $\mathrm{N}$ & 7 & 7 & 7 & 7 & 7 \\
\hline
\end{tabular}

Source: Calculated by researchers by using SPSS software.

**. Correlation is significant at the 0.01 level (1-tailed).

*. Correlation is significant at the 0.05 level (1-tailed).

\section{Empirical Results and Discussion}

Using the DEA Software and the available data for the seven Bahraini retail commercial banks, we computed the relative efficiency of these banks over the period of 2008 to 2012 and shown below in Figure (1).

According to Figure 1, the retail commercial banks that are efficient (non zero slacks) are: B1, B2, and B6 in years 2008 and 2009. B2 and B6 in years 2010 and 2011, while in year 2012 B5 and B6 were efficient. B4 appears to be the less efficient bank and B3 is close to become relatively efficient.

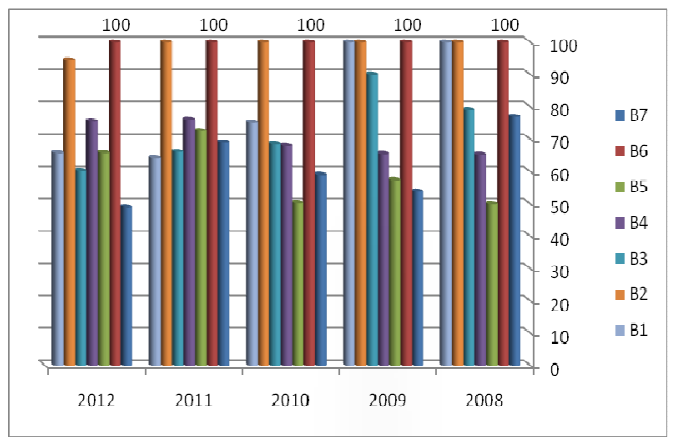

Source: calculated by researchers by using DEA frontier software

Figure 1. Relative Efficiency of Each Retail Commercial Bank (2008-2012)

Table 5 presents the efficient peers of each DMU and the relevant weight, the lambda value, so that a virtual DMU can be formed as a weighted combination of some efficient
DUMs. For instance in year 2008, B3 has as efficient peers $\mathrm{B} 1, \mathrm{~B} 2$ and B6. So the reference set of B3 is $\{\mathrm{B} 1, \mathrm{~B} 2, \mathrm{~B} 6\}$ with weights $\{0.082,0.344,0.045\}$. For $B 3$ the results 0.082 , 0.344 and 0.045 indicate that the target of this DMU is to become $8.2 \%$ of $\mathrm{B} 1,34.4 \%$ of $\mathrm{B} 2$ and $4.5 \%$ of B6. In year 2009 B3 still has as efficient peers B1, B2, and B6 with different weights $\{0.102,0.340,0.072\}$, while in year 2010 and 2011 the reference banks of B3 are B2 and B6 with weights $\{0.252,0.115\}$ and $\{0.041,0.157\}$ respectively. In year 2012, B6 was the reference bank of B3 with weight 0.159 .

DMU movements towards efficient operation cloud involve scaling up or scaling down of size based on the efficiency of a hypothetical best-practice composite reference unit. This hypothesis identifies inputs that have to be reduced and output that need to be increased in order to make a particular DMU efficient. This information may help the decision makers to determine whether the size of reprehensive DMU in the particular industry is appropriate or not (Kumar and Gulati, 2008).

The range of improvements (in Million BDs) needed for DMUs inputs and outputs to reach the efficiency are illustrated in Tables 6-10 (based on CRS assumption with input orientation). Table 6 shows the potential improvement in year 2008 for inefficient banks (B3, B4, B5, and B7) whereas B1, B2 and B6 are efficient and, therefore require no change in their inputs and outputs.

Table 5. Efficient Peers and Weights of Retail Commercial Banks (2008-2012)

\begin{tabular}{|c|c|c|c|c|c|c|c|c|c|c|}
\hline \multirow{3}{*}{ DMU No. } & \multirow{3}{*}{ DMU Name } & \multicolumn{9}{|c|}{ Input-Oriented } \\
\hline & & \multirow{2}{*}{$\begin{array}{l}\text { CRS } \\
\text { Efficiency }\end{array}$} & \multirow{2}{*}{$\begin{array}{l}\text { Sum of } \\
\text { lambdas }\end{array}$} & \multirow{2}{*}{ RTS } & \multicolumn{6}{|l|}{ Optimal Lambdas } \\
\hline & & & & & \multicolumn{6}{|l|}{ with Benchmarks } \\
\hline \multicolumn{11}{|l|}{2008} \\
\hline 1 & B1 & 1.00000 & 1.000 & Constant & 1.000 & B1 & & & & \\
\hline 2 & B2 & 1.00000 & 1.000 & Constant & 1.000 & B2 & & & & \\
\hline 3 & B3 & 0.79068 & 0.470 & Increasing & 0.082 & B1 & 0.344 & B2 & 0.045 & B6 \\
\hline 4 & B4 & 0.65218 & 0.138 & Increasing & 0.059 & B2 & 0.079 & B6 & & \\
\hline 5 & B5 & 0.50008 & 0.030 & Increasing & 0.030 & B6 & & & & \\
\hline 6 & B6 & 1.00000 & 1.000 & Constant & 1.000 & B6 & & & & \\
\hline 7 & B7 & 0.76968 & 0.093 & Increasing & 0.093 & B6 & & & & \\
\hline \multicolumn{11}{|l|}{2009} \\
\hline 1 & B1 & 1.00000 & 1.000 & Constant & 1.000 & $\mathrm{~B} 1$ & & & & \\
\hline 2 & $\mathrm{~B} 2$ & 1.00000 & 1.000 & Constant & 1.000 & B2 & & & & \\
\hline 3 & B3 & 0.90026 & 0.515 & Increasing & 0.102 & $\mathrm{~B} 1$ & 0.340 & B2 & 0.072 & B6 \\
\hline 4 & B4 & 0.65446 & 0.147 & Increasing & 0.058 & $\mathrm{~B} 1$ & 0.070 & B2 & 0.019 & B6 \\
\hline 5 & B5 & 0.57396 & 0.037 & Increasing & 0.037 & B6 & & & & \\
\hline 6 & B6 & 1.00000 & 1.000 & Constant & 1.000 & B6 & & & & \\
\hline 7 & B7 & 0.53846 & 0.062 & Increasing & 0.062 & B6 & & & & \\
\hline \multicolumn{11}{|l|}{2010} \\
\hline 1 & B1 & 0.75155 & 0.519 & Increasing & 0.519 & B6 & & & & \\
\hline 2 & $\mathrm{~B} 2$ & 1.00000 & 1.000 & Constant & 1.000 & B2 & & & & \\
\hline
\end{tabular}




\begin{tabular}{|c|c|c|c|c|c|c|c|c|}
\hline \multirow{3}{*}{ DMU No. } & \multirow{3}{*}{ DMU Name } & \multicolumn{7}{|c|}{ Input-Oriented } \\
\hline & & \multirow{2}{*}{\begin{tabular}{l|} 
CRS \\
Efficiency \\
\end{tabular}} & \multirow{2}{*}{$\begin{array}{l}\begin{array}{l}\text { Sum of } \\
\text { lambdas }\end{array} \\
\end{array}$} & \multirow{2}{*}{ RTS } & \multicolumn{4}{|l|}{ Optimal Lambdas } \\
\hline & & & & & with Benchmarks & & & \\
\hline 3 & B3 & 0.68522 & 0.367 & Increasing & 0.252 & B2 & 0.115 & B6 \\
\hline 4 & B4 & 0.67998 & 0.122 & Increasing & 0.085 & B2 & 0.037 & B6 \\
\hline 5 & B5 & 0.50298 & 0.043 & Increasing & 0.043 & B6 & & \\
\hline 6 & B6 & 1.00000 & 1.000 & Constant & 1.000 & B6 & & \\
\hline 7 & B7 & 0.59027 & 0.053 & Increasing & 0.053 & B6 & & \\
\hline \multicolumn{9}{|l|}{2011} \\
\hline 1 & B1 & 0.64109 & 0.545 & Increasing & 0.144 & B2 & 0.401 & B6 \\
\hline 2 & B2 & 1.00000 & 1.000 & Constant & 1.000 & B2 & & \\
\hline 3 & B3 & 0.66091 & 0.197 & Increasing & 0.041 & B2 & 0.157 & B6 \\
\hline 4 & B4 & 0.75547 & 0.148 & Increasing & 0.116 & B2 & 0.032 & B6 \\
\hline 5 & B5 & 0.72523 & 0.057 & Increasing & 0.057 & B6 & & \\
\hline 6 & B6 & 1.00000 & 1.000 & Constant & 1.000 & B6 & & \\
\hline 7 & B7 & 0.69470 & 0.059 & Increasing & 0.059 & B6 & & \\
\hline \multicolumn{9}{|l|}{2012} \\
\hline 1 & B1 & 0.65689 & 1.016 & Decreasing & 0.623 & B4 & 0.394 & B6 \\
\hline 2 & B2 & 0.94472 & 1.912 & Decreasing & 1.813 & B4 & 0.099 & B6 \\
\hline 3 & B3 & 0.60303 & 0.159 & Increasing & 0.159 & B6 & & \\
\hline 4 & B4 & 1.00000 & 1.000 & Constant & 1.000 & B4 & & \\
\hline 5 & B5 & 0.65752 & 0.050 & Increasing & 0.050 & B6 & & \\
\hline 6 & B6 & 1.00000 & 1.000 & Constant & 1.000 & B6 & & \\
\hline 7 & B7 & 0.49011 & 0.041 & Increasing & 0.041 & B6 & & \\
\hline
\end{tabular}

Table 6 shows that the efficiency of B 3 can be improved by decreasing total deposits from 3324.3 to 2295.256 (a slack of 1029.044), and increasing net loans from 1095.7 to 1097.70001. The efficiency of B4 can be improved by decreasing the overheads expenses by 2.6 to reach 6.63 and increasing interest income by 24,884 to reach its 40.384 . The efficiency of B5 can be achieved by decreasing total deposits and equity by 124.542 and 5.005 respectively, moreover, increasing net loans by 38.605. The efficient input target of B7 is decreasing the overheads expenses and equity to 8.359 and 105.6 respectively and increasing net loans to 478.202 Million Bahraini Dinars.

Table 7 shows the areas of improvements in year 2009 for
Banks B3, B4, B5 and B7 while B1, B2 and B6 are efficient and they do not need any adjustment in their inputs and outputs.

It can be deducted from Table 7 that the efficiency of B3 can be improved by decreasing total deposits to 1763.042 (a slack of 1249.412). The efficiency of B4 can be improved by decreasing the overheads expenses from 15.3 to 11.718 . The efficiency of B5 can be achieved by decreasing total deposits and equity to 187.09 and 36.474 respectively, and increasing net loans to187.921, the efficient input target of B7 is to decrease the overheads expenses and equity by 2.198 and 7.378 respectively and increasing net loans by 121.103 Million BD.

Table 6. CRS Model Slacks and Model Target for 2008

\begin{tabular}{|c|c|c|c|c|c|c|}
\hline \multicolumn{7}{|c|}{ CRS Model Slacks } \\
\hline & & Input Slacks & & & Output Slacks & \\
\hline DMU No. & DMU Name & & & Input & Output & \\
\hline 1 & $\mathrm{~B} 1$ & 0.00000 & 0.00000 & 0.00000 & 0.00000 & 0.00000 \\
\hline 2 & B2 & 0.00000 & 0.00000 & 0.00000 & 0.00000 & 0.00000 \\
\hline 3 & B3 & 1029.044 & 0.00000 & 0.00000 & 0.00001 & 0.00000 \\
\hline 4 & B4 & 0.00000 & 2.63072 & 0.00000 & 0.00000 & 24.88467 \\
\hline 5 & B5 & 124.54242 & 0.00000 & 5.00568 & 38.60554 & 0.00000 \\
\hline 6 & B6 & 0.00000 & 0.00000 & 0.00000 & 0.00000 & 0.00000 \\
\hline 7 & B7 & 0.00000 & 4.18451 & 22.13562 & 338.10224 & 0.00000 \\
\hline \multicolumn{7}{|c|}{ CRS Model Target } \\
\hline & & Efficient Input Target & & & Efficient Output Target & \\
\hline DMU No. & DMU Name & & & & Output & \\
\hline 1 & B1 & 13075.00000 & 53.90000 & 726.60000 & 4895.10000 & 108.80000 \\
\hline 2 & B2 & 2923.70000 & 35.10000 & 209.30000 & 1352.30000 & 56.60000 \\
\hline 3 & B3 & 2295.25634 & 24.05542 & 217.39409 & 1095.70001 & 49.40000 \\
\hline 4 & B4 & 867.46281 & 6.63018 & 128.6123 & 486.90000 & 40.38467 \\
\hline 5 & B5 & 146.65194 & 3.40028 & 57.64950 & 151.70554 & 13.80000 \\
\hline 6 & B6 & 4968.10000 & 57.60000 & 902.80000 & 5139.30000 & 467.50000 \\
\hline 7 & B7 & 600.60240 & 8.35957 & 105.60385 & 478.20224 & 43.50000 \\
\hline
\end{tabular}


Table 7. CRS Model Slacks and Model Target for 2009

\begin{tabular}{|c|c|c|c|c|c|c|}
\hline \multicolumn{7}{|c|}{ CRS Model Slacks } \\
\hline & & Input Slacks & & & Output Slacks & \\
\hline DMU No. & DMU Name & & & Input & Output & \\
\hline 1 & B1 & 0.00000 & 0.00000 & 0.00000 & 0.00000 & 0.00000 \\
\hline 2 & B2 & 0.00000 & 0.00000 & 0.00000 & 0.00000 & 0.00000 \\
\hline 3 & B3 & 1249.41223 & 0.00000 & 0.00000 & 0.00001 & 0.00000 \\
\hline 4 & B4 & 0.00000 & 3.29487 & 0.00000 & 0.00000 & 0.00000 \\
\hline 5 & B5 & 117.33448 & 0.00000 & 5.82655 & 69.52197 & 0.00000 \\
\hline 6 & B6 & 0.00000 & 0.00000 & 0.00000 & 0.00000 & 0.00000 \\
\hline 7 & B7 & 0.00000 & 2.19805 & 7.37872 & 121.10329 & 0.00000 \\
\hline \multicolumn{7}{|c|}{ CRS Model Target } \\
\hline DMU No. & DMU Name & Efficient Input Target & & Input & $\begin{array}{l}\text { Efficient Output Target } \\
\text { Output }\end{array}$ & \\
\hline 1 & B1 & 6834.00000 & 46.30000 & 671.50000 & 3508.70000 & 77.90000 \\
\hline 2 & B2 & 3273.40000 & 43.00000 & 231.00000 & 1268.60000 & 57.00000 \\
\hline 3 & B3 & 1763.04213 & 25.72674 & 241.32308 & 1151.40001 & 52.70000 \\
\hline 4 & B4 & 747.74207 & 11.71841 & 112.69255 & 388.00000 & 15.30000 \\
\hline 5 & B5 & 187.09370 & 3.50886 & 36.47428 & 187.92197 & 13.20000 \\
\hline 6 & B6 & 4992.00000 & 53.60000 & 973.20000 & 5014.10000 & 352.20000 \\
\hline 7 & B7 & 579.12283 & 8.24810 & 118.79046 & 313.20329 & 22.00000 \\
\hline
\end{tabular}

Table 8. CRS Model Slack and Model Target for 2010

\begin{tabular}{|c|c|c|c|c|c|c|}
\hline \multicolumn{7}{|c|}{ CRS Model Slacks } \\
\hline & & Input Slacks & & & Output Slacks & \\
\hline DMU No. & DMU Name & & & Input & Output & \\
\hline 1 & B1 & 1669.84650 & 0.00000 & 185.22168 & -0.00002 & 115.97609 \\
\hline 2 & B2 & 0.00000 & 0.00000 & 0.00000 & 0.00000 & 0.00000 \\
\hline 3 & B3 & 1085.02923 & 0.00000 & 0.00000 & 0.00002 & 0.68896 \\
\hline 4 & B4 & 0.00000 & 5.89146 & 0.00000 & 0.00000 & 2.73666 \\
\hline 5 & B5 & 13.71375 & 0.26924 & 0.00000 & 81.66294 & 0.00000 \\
\hline 6 & B6 & 0.00000 & 0.00000 & 0.00000 & 0.00000 & 0.00000 \\
\hline 7 & B7 & 0.00000 & 6.76733 & 14.62384 & 86.88310 & 0.00000 \\
\hline \multicolumn{7}{|c|}{ CRS Model Target } \\
\hline & & Efficient Input Target & & & Efficient Output Target & \\
\hline$D M U N o$. & DMU Name & & & Input & Output & \\
\hline 1 & B1 & 4416.16580 & 37.18256 & 538.75128 & 2833.99998 & 174.87609 \\
\hline 2 & B2 & 3384.40000 & 45.60000 & 240.50000 & 1276.30000 & 56.60000 \\
\hline 3 & B3 & 2683.78842 & 25.7787 & 263.21360 & 950.80002 & 53.08896 \\
\hline 4 & B4 & 727.72395 & 11.87216 & 85.4009 & 310.00000 & 17.23666 \\
\hline 5 & B5 & 488.13491 & 4.89596 & 88.16294 & 233.36294 & 14.40000 \\
\hline 6 & B6 & 5593.10000 & 53.70000 & 1037.60000 & 5458.10000 & 336.80000 \\
\hline 7 & B7 & 503.56798 & 9.85401 & 104.14561 & 290.08310 & 17.90000 \\
\hline
\end{tabular}

Table 8 illustrates the areas of improvements in year 2010 for banks, B1, B3, B4, B5 and B7, while B2 and B6 are efficient. As shown B1 needs a lot of adjustments to achieve efficiency, where B1 needs to decrease total deposits and equity by $27 \%$ and $34.4 \%$ respectively, and increasing interest income by $197 \%$ (from 58.9 to 174.87). The efficiency of B3 can be improved by decreasing total deposits by $28 \%$ (a slack of 1085.02) and increasing interest income by almost $1 \%$ (a slack of 0.688 ). The efficiency of B4 can be improved by decreasing the overheads expenses by $34 \%$ and increasing interest income by $19 \%$. The efficiency of B5 can be achieved by decreasing total deposits and equity by $2 \%$ and $0.5 \%$ respectively and increasing net loans by $8 \%$ (from 151.7 to 233.36). The efficient input target of $\mathrm{B} 7$ is to decrease the overheads expenses and equity by $41.5 \%$ and $12.4 \%$ respectively and increasing net loans by $42.7 \%$.

Table 9 shows the same results that illustrated in table(8), where Banks, B1, B3, B4, B5, and B7 are still need some improvements in inputs and outputs to reach the efficiency, while Banks B2 and B6 are efficient and require no changes in their inputs and outputs. The big adjustment should happen in B7 in order to improve it and reach efficiency, where B7 should decrease its overheads expenses from 17.2 to 3.23 , decrease equity from 118.9 to 64.5 , and increase net loans from 201.6 to 343.647 Million BDs.

Table 10 shows the areas of improvements in year 2012 for inefficient banks, which are B1, B2, B3, B5 and B7, whereas only banks $\mathrm{B} 4$ and $\mathrm{B} 6$ are efficient and require no changes in their inputs and outputs. The efficiency of B1 can be improved by decreasing total deposits from 8212 to 6263.2 and increasing interest income from 60.7 to 168.6. The efficiency of B2 can be improved by decreasing total deposits from 4712 to 3087.69 and decreasing the overheads expenses from 50.5 to 42.44 . 
Table 9. CRS Model Slack and CRS Model Target for 2011

\begin{tabular}{|c|c|c|c|c|c|c|}
\hline \multicolumn{7}{|c|}{ CRS Model Slacks } \\
\hline & & Input Slacks & & & Output Slacks & \\
\hline DMU No. & DMU Name & & & Input & Output & \\
\hline 1 & B1 & 1321.49580 & 0.00000 & 0.00001 & -0.00002 & 99.25155 \\
\hline 2 & B2 & 0.00000 & 0.00000 & 0.00000 & 0.00000 & 0.00000 \\
\hline 3 & B3 & 1450.27131 & 7.08140 & 0.00000 & 0.00002 & 0.00000 \\
\hline 4 & B4 & 0.00000 & 6.96428 & 0.00000 & 0.00000 & 5.23806 \\
\hline 5 & B5 & 0.00000 & 0.56822 & 7.59045 & 191.31035 & 0.00000 \\
\hline 6 & B6 & 0.00000 & 0.00000 & 0.00000 & 0.00000 & 0.00000 \\
\hline 7 & B7 & 0.00000 & 13.71347 & 54.40048 & 142.04706 & 0.00000 \\
\hline \multicolumn{7}{|c|}{ CRS Model Target } \\
\hline & & Efficient Input Target & & & Efficient Output Target & \\
\hline DMUNo. & DMU Name & & & Input & Output & \\
\hline 1 & B1 & 5799.51635 & 45.20000 & 740.65642 & 2547.79998 & 156.25155 \\
\hline 2 & B2 & 4295.90000 & 47.90000 & 238.00000 & 1406.70000 & 61.40000 \\
\hline 3 & B3 & 2558.3433 & 19.56485 & 274.36142 & 972.10002 & 60.00000 \\
\hline 4 & B4 & 93619201 & 12.31404 & 82.92816 & 349.60000 & 18.83806 \\
\hline 5 & B5 & 513.18733 & 4.63045 & 89.46664 & 332.51035 & 20.90000 \\
\hline 6 & B6 & 6539.10000 & 55.00000 & 1097.50000 & 5842.00000 & 367.20000 \\
\hline 7 & B7 & 553.65294 & 3.23529 & 100.55882 & 343.64706 & 21.60000 \\
\hline
\end{tabular}

Table 10. CRS Model Slack and Model Target for 2012

\begin{tabular}{lllllll}
\hline \multicolumn{2}{l}{ CRS Model Slacks } & \multicolumn{5}{l}{ Output Slacks } \\
\hline \multicolumn{7}{l}{ Input Slacks } \\
\hline DMU No. & DMU Name & & & \\
1 & B1 & 1948.83645 & 0.00000 & 0.00000 & -0.00001 & 107.96413 \\
2 & B2 & 1625.81950 & 8.26421 & 0.00000 & -0.00001 & 0.00000 \\
3 & B3 & 1556.45283 & 7.50420 & 0.00000 & 72.58742 & 0.00000 \\
4 & B4 & 0.00000 & 0.00000 & 0.00000 & 0.00000 & 0.00000 \\
5 & B5 & 0.00000 & 1.29443 & 8.98781 & 185.68119 & 0.00000 \\
6 & B6 & 0.00000 & 0.00000 & 0.00000 & 0.00000 & 0.00000 \\
7 & B7 & 0.00000 & 5.18941 & 8.99775 & 1.95639 & 0.00000 \\
CRS Model Target & & & & & \\
& & Efficient Input Target & & & Efficient Output Target \\
DMU No. & DMU Name & & & & Input & Output \\
1 & B1 & 6263.17116 & & 51.36431 & 803.81082 & 2683.09999 \\
2 & B2 & 3087.69595 & & 42.44409 & 289.68506 & 1498.69999 \\
3 & B3 & 2843.71287 & & 20.95861 & 318.90733 & 960.78742 \\
4 & B4 & 1184.60000 & & 18.70000 & 85.40000 & 499.10000 \\
5 & B5 & 518.09406 & & 5.08218 & 95.72277 & 298.38119 \\
6 & B6 & 6880.00000 & & 56.20000 & 1206.40000 & 6027.30000 \\
7 & B7 & 576.79307 & & 10.20921 & 100.56990 & 247.65639 \\
\hline
\end{tabular}

\section{Conclusion and Recommendations}

\subsection{Conclusions}

Based on the study results, 4 banks out of 7 were technically inefficient under variable returns to scale (VRS), with an overall average score of $0.816(81.6 \%)$ during years 2008 and 2009, while 5 banks out of 7 were technically inefficient under variable returns to scale (VRS), with an overall average score of $0.754(75.4 \%)$ during years 2010 , 2011 and 2012. These results are consistent with other studies carried out in developing countries, which showed that technical inefficiency exists in the banking sector.

The allocative efficiency scores averaged around 0.917 for the banks under study over the period (2008-2012). Bank 6 (B6) is found to be the most allocative efficient and realized an efficient score the highest, while Bank 5 (B5) found to be the least for years 2008 to 2010 and Bank 7(B7) was the least for years 2011 and 2012 .

The DEA model provides useful information on inefficient banks to achieve efficiency by either decreasing inputs and/or increasing outputs, where it provides the actual and target values of inputs and outputs for the technically inefficient banks as shown in tables (6-10).

Finally, while the kingdom of Bahrain has implemented many economic and financial reforms over the last decades or so, these do appear to have positive impact on the efficiency of the sample of retail commercial banks under 
study and it shows an increasing trend in performance of these banks caused by IT innovation, competition, better supervision, and enlarged investment in new information technology during the recent time period. The banks were left with no option but to improve their functional operations, strategies and policies. In this paper, the authors' propose was to assess banks' relative efficiencies and to recommend further research areas. In comparison with international standards, Bahraini banks would need to improve their technological orientation, to continue their efforts to reduce the percentage of non-performing assets and expand the possibilities for augmenting their financial activities in order to improve their profit efficiency in the near future.

\subsection{Recommendations for Further Study}

The paper could be extended in a variety of ways. Firstly, the scope of the paper could be extended to compare relative efficiency of commercial banks with that of Islamic banks. Secondly, the performance of commercial banks could be extended by considering the risk exposure factor. Thirdly, future research could investigate changes in productivity of commercial banks over time as a result of technical change or technological progress or regress by employing the Malmquist total factor productivity index.

\section{References}

[1] AlKhathlan, K., \& Malik, S. A. (2010). Are Saudi banks efficient? Evidence using data envelopment analysis (DEA). International Journal of Economics and Finance, 2(2), 53-59.

[2] Berger, A. N., \& Humphrey, D. B. (1997). Efficiency of financial institutions: international survey and directions for future research. European Journal of Operational Research, 98(2), 175-212.

[3] Bilal, H., \& Khursheed, A. (2011). Returns to scale of Islamic banks vs small commercial banks in Pakistan. European Journal of Economics Finance and Administrative Sciences, (30), 136-152.

[4] Boussofiane, A., Dyson, R., \& Rhodes, E. (1991). Applied DEA. European Journal of Operational Research, 2(6), 1-15.
[5] Jones, J., Izzeldin, M., \& Pappas V. (2012). A comparison of performance of Islamic and Conventional Banks 2004 to 2009. Lancaster University Management School Working Paper, April.

[6] Kamaruddin, B. H., Safa, M. S., \& Rohani, M (2008). Assessing production efficiency of Islamic banks and conventional banks Islamic windows in Malaysia. International Journal of Business and Management Sciences, $1(1), 31-48$

[7] Kumar S, and Gulati, R, (2008). An Examination of Technical, Pure Technical, and Scale Efficiencies in Indian Public Sector Banks using Data Envelopment Analysis. Eurasian Journal of Business and Economics, 1(2), 33-69.

[8] Marie, A., Al-Nasser, A., \& Ibrahim, M. (2013). Operationalprofitability-quality performance of Dubai's banks: Parallel DEA analysis. Journal of Management Research, 13(1): 25-34.

[9] Mostafa, M. (2007). Benchmarking top Arab bank's efficiency through efficient frontier analysis. Industrial Management and Data Systems, 107(6), 802-23.

[10] Qureshi, M. A. \& Shaikh, M. (2012). Efficiency of Islamic and conventional banks in Pakistan: A nonparametric approach. International Journal of Business and Management, $7(7), 40-51$.

[11] Rahman, M. M. (2011). Different parametric and nonparametric approaches to model the efficiency of Islamic and conventional banks in Bangladesh. International Journal of Business and Management Sciences, 4(2), 147-175.

[12] Shahid, H., Rehman, R., Niazi, G. S. K., \& Raoof, A. (2010). Efficiencies comparison of Islamic and conventional banks of Pakistan. International Research Journal of Finance and Economics, 49, 24-42.

[13] Srairi, S. A., (2010). Efficiency of the Saudi Banking Sector: A DEA approach. Bankers Markets and Investors, 108, September-October, 31-46.

[14] Srairi, S. A., (2011) Productivity growth in the GCC banking industry: conventional vs. Islamic banks. Journal of Knowledge Globalization, 4(2): 59-90.

[15] Tone, K. (2001). A slacks-based measure of efficiency in DEA. European Journal of Operational Research, 130, 498-509.

[16] Tone, (2002). A slacks-based measure of super-efficiency in DEA, European Journal of Operational Research, 143, 32-41. 